ISSN 1112-9867

Available online at

http://www.jfas.info

\title{
BACTERIOLOGICAL ANALYSIS AND PUBLIC PERCEPTION ABOUT DRINKING WATER OF BOREHOLES IN ARIB (AIN DEFLA, ALGERIA)
}

\author{
F. Hamaidi-Chergui ${ }^{1, *}$, M. Brahim Errahmani ${ }^{2}$, A. Debib ${ }^{3}$ and M.S. Hamaidi ${ }^{1}$ \\ ${ }^{1}$ Laboratoire de Biotechnologies, Environnement et Santé, Département de Biologie et \\ Physiologie Cellulaire, Faculté des Sciences de la Nature et de la Vie, Université Blida 1, \\ Algérie \\ ${ }^{2}$ Département de Chimie, Faculté des Sciences, Université Blida 1, Algérie \\ ${ }^{3}$ Département de Biologie et physiologie cellulaire, Faculté des Sciences de la Nature et de la \\ Vie, Université Blida 1, Algérie
}

Received: 14 December 2016 / Accepted: 27 Mars 2016 / Published online: 01 May 2016

\begin{abstract}
Water from boreholes in Arib (Ain Defla) was investigated to ascertain its quality status and suitability for drinking and domestic uses. Fifty six water samples were collected from four boreholes. The analyses of the Coliform counts obtained from various boreholes samples ranged between 0 and $200 \mathrm{CFU} / 100 \mathrm{ml}$ with regard to total Coliforms and between 0 and 8 CFU/ $100 \mathrm{ml}$ with regard to fecal Coliforms. Three of the boreholes samples showed contamination by Streptococcus sp. Pathogens like Salmonella were not identified but some low levels of sulfite-reducing bacteria was found. The interviews were done to assess perceptions on water taste problems, odour, colour, turbidity and health problems.

These results showed that all the samples did not satisfy the WHO and JORA requirements for bacteriological characteristics in human consumption.
\end{abstract}

Keywords: boreholes; bacteriological analysis; water quality; Arib; Ain Defla; Algeria.

Author Correspondence, e-mail: hamaidifella@yahoo.fr

doi: http://dx.doi.org/10.4314/jfas.v8i2.24 


\section{INTRODUCTION}

Public and environmental health protection requires safe drinking water. Present day water sources are being polluted largely by agricultural and industrial chemical waste disposals due to cross contamination with sewers. Contamination of groundwater has severe implications for public health, particularly in small communities and developing countries where groundwater is often the preferred source of drinking water [1].

The availability of good quality water is an indispensable feature for preventing disease and improving quality of life [2]. The known pathogenic organisms cause disease from mild gastroenteritis to severe and sometimes fatal dysentery, cholera, or typhoid [3].

Human activities at the land surface may cause groundwater contamination by bacterial pathogens. In general, the microbiological quality of groundwater will be better than that of surface water, since pathogens will be filtered by the soil and subsoil during the recharge process [4].

Natural groundwater is usually of good quality, but this can deteriorate due to inadequate source protection and poor resource management [5].

Coliforms bacteria are commonly used bacterial indicator of water pollution, which are present in the environment particularly in the faeces of all warm-blooded animals and humans [6]. Their presence in drinking water indicates that disease-causing organisms could be in the water system and may pose an immediate health risk [7]. Water for human consumption must be free from organisms and chemical substances in concentration large enough to affect health [8].

In Algeria, the two major sources of drinking water are surface water and groundwater. But, the overexploitation of aquifers and reduced natural recharge due to high urbanization and anthropogenic activity has caused a decrease in groundwater quality in many areas. The physico-chemical parameters were analyzed [9], but any works has been done on the suitability of ground water for human consumption in the study area.

The aim of this study was to determine the bacteriological quality of the water produced by these boreholes and it's evaluation for human consumption, by comparing the results of the bacteriological analysis to the WHO and JORA drinking water standards.

\section{MATERIALS AND METHODS}

\subsection{Study area}

The study area, as shown in figure 1, is Arib which is a medium size community of Ain Defla, 
located $145 \mathrm{kms}$ South West of Algiers (36¹7'16.09"N 2 $\left.3^{\circ} 56.96 " E\right)$, it shares a boundary with Tipaza in the North, Tissemsilt in the South, Chlef in the West and Blida in the East.

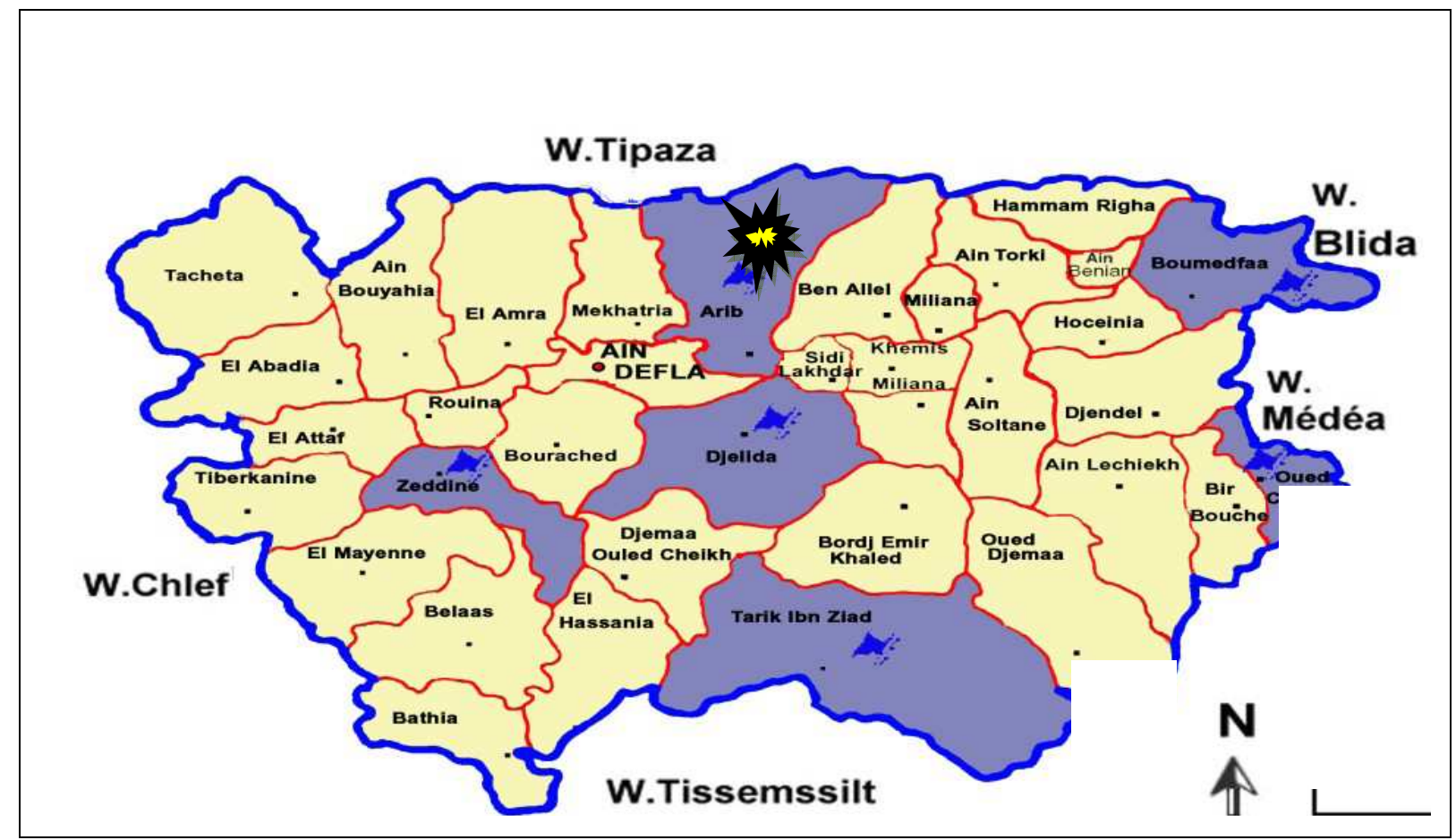

Fig.1. Location of Arib area in Ain Defla (Algeria) (Agence nationale de Développement de l'Investissement (ANDI), 2013)

\subsection{Sample collection and analysis of water}

Four boreholes were sampled; their characteristics are shown in (Tab. 1). For each borehole (BH), water samples were collected from March to June in the year of 2011. A water sample of $100 \mathrm{ml}$ is drawn through a membrane filter $(0.45 \mu \mathrm{m}$ pore size $)$ using a vacuum pump. The filter is placed on a Petri dish containing selective agar Table 2.

Results were expressed as the most probable number per $100 \mathrm{ml}\left(\mathrm{CFU} 100 \mathrm{ml}^{-1}\right)$. The total, fecal and Streptococci Coliforms were analyzed by the membrane filter technique according to standard methods for the examination of water and wastewater, the sulfito-reducing bacteria by meat-liver agar supplemented with sodium sulfite and iron alun. The salmonella were analyzed by Sodium Tellurite Broth (TCB) enrichment and Hecktoen agar. The samples were taken before the chlorine dispenser to determine the natural conditions of the aquifer. All the results were compared to standards of World Health Organization and JORA $[10,11]$. 
Table 1. Characteristics of the Sampled Boreholes (BH) (Algérienne Des Eaux (ADE), 2010)

\begin{tabular}{ccccc}
\hline Boreholes & BH1 & BH2 & BH3 & BH4 \\
\hline Depth (m) & 65 & 70 & 120 & 58 \\
\hline Flow (1/s) & 40 & 30 & 20 & 20 \\
\hline Date of commissioning & 1982 & 1982 & 1992 & 1994 \\
\hline
\end{tabular}

Table 2. Selective medium used for the enumeration of pathogens in water

\begin{tabular}{ccc}
\hline Total Coliforms & TTC agar & $37^{\circ} \mathrm{C} / 24 \mathrm{~h}$ \\
\hline Fecal Coliforms & TTC agar & $44^{\circ} \mathrm{C} / 24 \mathrm{~h}$ \\
\hline Fecal Streptococci & Slanetz and Bartly agar & $37^{\circ} \mathrm{C} / 24 \mathrm{~h}$ \\
\hline $\begin{array}{c}\text { Sulfite-reducing } \\
\text { bacteria }\end{array}$ & $\begin{array}{c}\text { Meat-liver agar supplemented with } \\
\text { sodium sulfite and iron alun }\end{array}$ & $37^{\circ} \mathrm{C} / 24 \mathrm{~h}$ and $48 \mathrm{~h}$ \\
\hline Salmonella & $\begin{array}{c}\text { Sodium Tellurite Broth } \\
\text { (TCB) enrichment and Hecktoen agar }\end{array}$ & $37^{\circ} \mathrm{C} / 24 \mathrm{~h}$ \\
\hline
\end{tabular}

\subsection{Interviews}

The interviews were done to assess perceptions on water taste problems, odor, color, turbidity and health problems. The respondents were taken from people in the community using random sampling technique. Sixty people were sampled at each area surrounding the borehole.

\section{RESULTS AND DISCUSSION}

\subsection{Bacteriological analysis}

Human activities at the land surface may cause groundwater contamination by bacterial pathogens. In general, the microbiological quality of groundwater will be better than that of surface water, since pathogens will be filtered by the soil and subsoil during the recharge process [4]. Coliforms bacteria are described and grouped based on their common origin or characteristics, as either total or fecal Coliforms. The total group includes fecal Coliform bacteria such as Escherichia coli (E.coli), as well as other types of Coliforms bacteria that are naturally found in the soil. Fecal Coliform bacteria exist in the intestines of warm blooded animals and humans, and are found in bodily waste, animal droppings, and naturally in soil. Most of the fecal Coliforms in fecal material comprised of E. coli, and the serotype E. coli 0157 is known to cause serious human illness [12]. In artificially drained fields, where 
subsurface drain tiles discharge to surface waters, tile drainage water may become a pathway for bacterial contamination of the receiving surface water, as well as the groundwater [13, 14]. The bacterial counts of all water samples ranged between 0 and 200 (CFU/100 ml) with regard to total Coliforms and between 0 and 8 (CFU/100 ml) with regard to fecal Coliforms. The highest total Coliform counts were recorded in boreholes BH2 and BH4 (Tab. 3), those of fecal Coliform were recorded in borehole BH4. The high Coliform count obtained in BH4 may be an indication that the water sources are fecally contaminated. The samples of the four boreholes contained feacal Coliform. However, various studies around the world assessing different water sources have revealed total Coliform contamination rates ranging from $0 \%$ to $100 \%[15,16]$.

Table 3. Results of bacterial analyses of boreholes samples

\begin{tabular}{|c|c|c|c|c|c|c|}
\hline & \multicolumn{4}{|c|}{ Mean \pm SE } & \multicolumn{2}{|c|}{$\begin{array}{c}\text { Water quality } \\
\text { standard for water } \\
\text { drinking }\end{array}$} \\
\hline Germs & BH1 & $\mathrm{BH} 2$ & $\mathrm{BH} 3$ & BH4 & $\begin{array}{l}\text { WHO } \\
{[10]}\end{array}$ & $\begin{array}{c}\text { JORA } \\
{[11]}\end{array}$ \\
\hline Total Coliforms (CFU/100ml) & $19 \pm 12$ & $77 \pm 33$ & $61 \pm 21$ & $72 \pm 32$ & 10 & 0 \\
\hline Fecal Coliforms (CFU/100ml) & $0.3 \pm 0.3$ & $0.4 \pm 0.3$ & $0.6 \pm 0.3$ & $3.1 \pm 1.3$ & 0 & 0 \\
\hline $\begin{array}{l}\text { Fecal Streptococci } \\
(\mathrm{CFU} / 100 \mathrm{ml})\end{array}$ & 0 & 0 & $2.0 \pm 2.0$ & $0.1 \pm 0.1$ & 0 & 0 \\
\hline $\begin{array}{l}\text { Sulfite-reducing bacteria } \\
\text { (spore } / 20 \mathrm{ml} \text { ) }\end{array}$ & 0 & $0.6 \pm 0.4$ & $0.6 \pm 0.4$ & $0.1 \pm 0.1$ & 0 & 0 \\
\hline
\end{tabular}

The WHO recommended levels $<10 \mathrm{CFU} /(100 \mathrm{ml})$. The median values for total Coliforms were 4, 23, 57 and $21 \mathrm{CFU} /(100 \mathrm{ml})$ in $\mathrm{BH} 1, \mathrm{BH} 2, \mathrm{BH} 3$ and $\mathrm{BH} 4$ respectively, only the $\mathrm{BH} 1$ was under the standards and only $39.3 \%$ of measured levels were under $10 \mathrm{CFU} /(100 \mathrm{ml})$.

The analyses of the Coliform counts obtained from various borehole samples are shown in figure 2. 

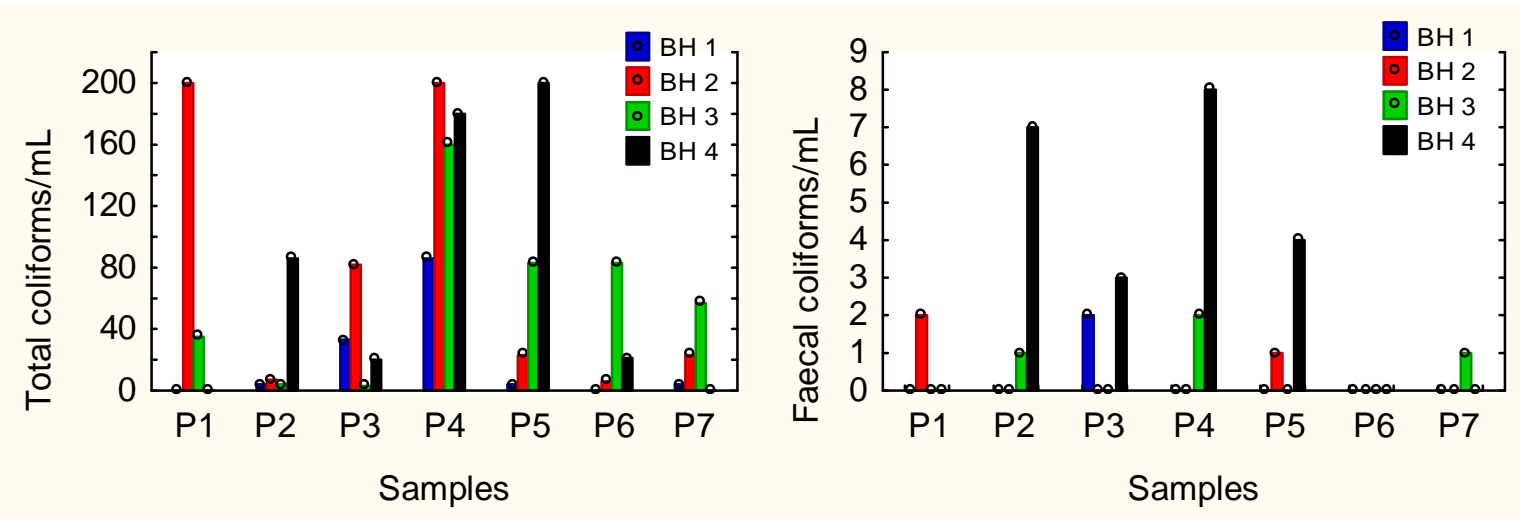

Fig.2. Comparison of Total Coliforms and Fecal Coliforms in differents water samples

Similarly, WHO [10] recommend no fecal Coliforms should be found in any water meant for drinking. Based on bacteriological analysis, therefore, one may conclude that borehole water samples not met the suitability requirements for drinking and domestic purposes, as fecal Coliforms bacteria were detected in them and some total Coliforms counts far more than the standards set by WHO (10 CFU/100 ml).

Three boreholes were confirmed to contain Streptococcus sp. and sulfite-reducing bacteria. Streptococcus sp. is an organism known to live as commensal in and on human body, and its presence in the waters suggests poor human handling. This was supported by the report of Pruss [17]. Fecal Streptococcus sp. is responsible for gastrointestinal illness among humans [18]. However, sulfite-reducing bacteria are forms of resistance anaerobic organisms. Their presence could be suitable indicators of past human pollution because they have a great longevity in natural habitats and they cannot multiply at temperatures below $\left(20^{\circ} \mathrm{C}\right)$ or in the presence of $\mathrm{O}_{2}$.

Pathogens as Salmonella were not detection in these water samples. It could be attributed to the fact that underground water is generally pure because of the purification properties of the soil [19].The less likelihood of having microorganisms is related to the depth of the groundwater [20].

The WHO [10] was used to categorize each well as follows: 
Table 4. Correlation of Total, fecal Coliform and Fecal streptococci levels with WHO disease risk categories

\begin{tabular}{cccc}
\hline Indicators organisms & \multicolumn{2}{c}{ Water quality assessment criteria } \\
\hline & Good & Marginal & Poor \\
\hline Total Coliform & $10 \mathrm{CFU} /(100 \mathrm{ml})$ & $11-150 \mathrm{CFU} /(100 \mathrm{ml})$ & $>100 \mathrm{CFU} /(100 \mathrm{ml})$ \\
\hline Fecal Coliform & $0 \mathrm{CFU} /(100 \mathrm{ml})$ & $1-10 \mathrm{CFU} /(100 \mathrm{ml})$ & $>10 \mathrm{CFU} /(100 \mathrm{ml})$ \\
\hline Fecal Streptococci & $0 \mathrm{CFU} /(100 \mathrm{ml})$ & $1 \mathrm{CFU} /(100 \mathrm{ml})$ & $>1 \mathrm{CFU} /(100 \mathrm{ml})$ \\
\hline
\end{tabular}

Good indicates negligible risk of microbial infections and fit for human consumption, Marginal indicates slight risk of microbial infection; must be treated before consumption, Poor indicates high risk of infectious disease transmission; not fit for human consumption.

These results showed that all the samples did not satisfy the WHO requirements for bacteriological characteristics in human consumption. A thorough treatment of water from these boreholes would be required before its domestic consumption.

\subsection{Community response to water problems}

More than $43 \%$ of the respondents rated their drinking water safe for consumption as well as absence of illness after drinking as indicators for judging the quality of the water. However, the others respondents $(56.7 \%)$ reported that they have had at least some concerns with safety of their water. More than $20 \%$ of the households reported at least one household member having suffered some water related illness in the past two years (Tab. 5). Yassin et al. [16] showed in a study conducted in the Gaza Strip between 2000 and 2006 that diarrheal diseases were strongly correlated with water contamination by fecal Coliforms. These data have shown again a very common problem, also reported by Amaral et al. [21], the lack of knowledge of consumers in relation to water, because most often associate the visual and organoleptic characteristics as decisive in the quality of water consumed. According to data from the questionnaires, $33 \%$ of the respondents were using the water only for human consumption, $53 \%$ for washing clothes and $14 \%$ of them said they did not use it at all.

Respondents were asked to judge the quality of the water, based on four sensory characteristics of drinking water. Many respondents rated the smell (33.3\%), taste $(20.0 \%)$, color $(23.3 \%)$ and turbidity $(23.3 \%)$ (Table 6). 
Table 5. Distribution of respondents according to the water quality and health outcome

\begin{tabular}{cccc}
\hline & $\begin{array}{c}\text { Distribution of respondents } \\
\text { according to the water quality }\end{array}$ & & $\begin{array}{c}\text { Relationship between drinking water } \\
\text { and health outcome }\end{array}$ \\
\hline Safe & $43.3 \%$ & Yes & $20 \%$ (suffered) \\
\hline Not safe & $56.7 \%$ & No & $80 \%$ (not suffered) \\
\hline
\end{tabular}

Table 6. Public perceptions to the borehole water problems expressed in percentages (\%) of the total respondents

\begin{tabular}{lllll}
\hline Parameters & Odor & Turbidity & Colour & Taste \\
\hline Percentages & $33.3 \%$ & $23,3 \%$ & $23,3 \%$ & $20 \%$ \\
\hline
\end{tabular}

\section{CONCLUSION AND RECOMMANDATIONS}

The water samples were found not corresponding to the bacteriological standards for drinking water suggested by WHO and JORA. The presence of fecal contamination in water samples indicates potentially dangerous situation which require immediate attention. Hence it is suggested that water from these sources should be pretreated before consumption. The sites of boreholes are very important as clean and hygienic environment promote safety of water.

The above recommendations are :

Wells constructed should be properly ringed and covered to avoid the washing of surface particles into the wells during rainy seasons.

The wells should be treated with chlorine from time to time before it reaches the consumer.

Water from the wells and boreholes should be boiled before drinking.

The communities should be educated on the need to keep their surroundings clean most especially around the boreholes.

\section{ACKNOWLEDGEMENTS}

The authors thank ADE of Ain Defla (Algeria).

\section{REFERENCES}

[1] Bitton G., Gerba C., Groundwater pollution microbiology: the emerging issue. In: Bitton, G., Gerba, C. Editors. Groundwater Pollution Microbiology. New York: John Wiley and Sons. 1984.

[2] Patil P.N., Sawant D.V., Deshmukh R.N., Physico-chemical parameters for testing of water 
-A review. International Journal of Environmental Sciences, 2012, 3 (3): 1194-1207.

[3] Mcfeters G.A., Survival and virulence of Water Born Pathogenic Bacteria in Potable Waters. Proceeding of the 1986 International Symposium on Aquifers. Prevention and Restoration. American Water Resources Association. 1987.

[4] Maier R.M., Pepper I.L., Gerba C.P., Environmental Microbiology. Academic Press. San Diego, CA. 2000.

[5] Pedley S., Howard G., The public health implications of microbiological contamination of groundwater. Q. J. Eng. Geol., 1997, 30 (2): 179-188.

[6] Howard G., Goldstein G., Morgan J., Pruss A., Shaw R.J., Healthy villages. A guide for communities and community health workers. WEDC, Loughborough University, 2002, 31: 23-29.

[7] Tebutt T., Principles of Water Quality Control. Pergamon Inc. England, 2007, 235-256.

[8] Brian O., Environmental Quality Centre Environmental Engineering and Earth Sciences Wilkes University. Wilkes- Barre, PA 1876, 2007.

[9] Hamaidi M.S., Hamaidi-Chergui F., Physico-chemical quality of boreholes water used as a soure of publics in Arib (Ain Defla, Algeria). European Academic Research., 2014, 53795392.

[10] WHO, Guidelines for Drinking Water Quality. Vol. 1, Recommendation. $3^{\text {rd }}$ Ed. WHO, Geneva. 2004.

[11] JORA. Décret exécutif $n^{\circ} 11-125$ du 17 Rabie Ethani 1432 correspondant au 22 mars 2011 relatif à la qualité de l'eau de consommation humaine. 2011.

[12] Pappas E.A., Kanwa R.S., Baker J.L, Lorimor J.C., Mickelson S., Fecal indicator bacteria in subsurface drain water following swine manure application. Agricultural and Biosystems Engineering, 2008, 51 (5): 1567-1573.

[13] Hunter C., Perkins J., Tranter J., Hardwick P., Fecal bacteria in the waters of an upland area in Derbyshire, England: The influence of agricultural land use. J. Environ. Qual., 2000, 29(4): 1253-1261.

[14] Monaghan R.M., Smith L.C., Minimising surface water pollution resulting from farm-dairy effluent application to mole-pipe drained soils: II. The contribution of preferential flow of effluent to whole-farm pollutant losses in subsurface drainage from a West Otago dairy farm. New Zealand J. Agric. Res., 2004, 47 (4): 417-428.

[15] Nogueira G., Nakamura C.V., Tognim M.C.B., Abreu Filho B.A., Dias Filho B.P., Microbiological quality of drinking water of urban and rural communities, Brazil. Revista de 
Saude Publica, 2003, 37: 232-236.

[16] Yassin M.M, Amr S.S.A., Al-Najar H.M., Microbial contamination of the drinking water distribution system and its impact on human health in Khan Yunis Governorate, Gaza Strip: Seven years of monitoring (2000 - 2006). Public Health, 2008, 122 (11): 1275-1283.

[17] Pruss A., Review of epidemiology study of health effects from exposure of recreational water. Int. J. Epidemiol., 1998, 27: 1-9.

[18] Donovan E., Unice K., Roberts J.D., Harris M., Finley, B. Risk of gastrointestinal disease associated with exposure too pathogens in the water of the lower Passaic River. Applied Environmental Microbiology, 2008, 74 (4): 994-1003.

[19] Shittu O.B., Olaitan J.O., Amusa T.S., Nigeria. African Journal of Biomedical Research, 2008, 11: 285-290.

[20] Eja M.E., Water Pollution and Sanitation for Developing Countries. Seaprint (NIG) CO. Calabar, Nigeria, 2002, 6-33.

[21] Amaral L.A.D., Filho A.N., Rossi Junior O.D., Ferreira F.L.A., Santana Soares L., Barros L., Drinking water in rural farms as a risk factor to human health. Rev Saúde Pública, 2003, 37(4): 510-514.

\section{How to cite this article:}

Hamaidi-Chergui F, Brahim Errahmani M, Debib A, Hamaidi M.S. Bacteriological analysis and public perception about drinking water of boreholes in Arib (Ain Defla, Algeria). J. Fundam. Appl. Sci., 2016, 8(2), 542-551. 